\title{
The relationship between irrigation water demand and drought in the Yellow River basin
}

\author{
Yu Wang ${ }^{1}$, Weihao Wang ${ }^{2}$, Shaoming Peng ${ }^{1}$, Guiqin Jiang ${ }^{1}$, and Jian Wu ${ }^{1}$ \\ ${ }^{1}$ Yellow River Engineering Consulting Co., Ltd., Zhengzhou, Henan, 450000, China \\ ${ }^{2}$ Institute of Hydrology and Water Resources Hohai University, Nanjing, 210000, China \\ Correspondence to: Yu Wang (happytimes@126.com)
}

Published: 17 October 2016

\begin{abstract}
In order to organize water for drought resistance reasonably, we need to study the relationship between irrigation water demand and meteorological drought in quantitative way. We chose five typical irrigation districts including the Qingtongxia irrigation district, Yellow River irrigation districts of Inner Mongolia in the upper reaches of the Yellow River, the Fen river irrigation district and the Wei river irrigation district in the middle reaches of the Yellow River and the irrigation districts in the lower reaches of the Yellow River as research area. Based on the hydrology, meteorology, groundwater and crop parameters materials from 1956 to 2010 in the Yellow River basin, we selected reconnaissance drought index (RDI) to analyze occurrence and evolution regularity of drought in the five typical irrigation districts, and calculated the corresponding irrigation water demand by using crop water balance equation. The relationship of drought and irrigation water demand in each typical irrigation district was studied by using grey correlation analysis and relevant analysis method, and the quantitative relationship between irrigation water demand and RDI was established in each typical irrigation district. The results showed that the RDI can be applied to evaluate the meteorological drought in the typical irrigation districts of the Yellow River basin. There is significant correlation between the irrigation water demand and RDI, and the grey correlation degree and correlation coefficient increased with increasing crops available effective rainfall. The irrigation water demand of irrigation districts in the upstream, middle and downstream of the Yellow River basin presented different response degrees to drought. The irrigation water demand increased 105 million $\mathrm{m}^{3}$ with the drought increasing one grade (RDI decreasing 0.5 ) in the Qingtongxia irrigation district and Yellow River irrigation districts of Inner Mongolia. The irrigation water demand increased 219 million $\mathrm{m}^{3}$ with the drought increasing one grade in the Fen river irrigation district and Wei river irrigation district. The irrigation water demand increased 622 million $\mathrm{m}^{3}$ with the drought increasing one grade in the downstream of Yellow River irrigation districts.
\end{abstract}

\section{Introduction}

The Yellow River Basin is one of the areas hardest hit by drought in history due to its low rainfall and high evaporation. Over the past 3710 years from 1766 to $1944 \mathrm{BC}$, the Yellow River basin experienced 107 droughts recorded in history. During the 25 years from 1950 and 1974, 17 droughts occurred, averagely once every one year and half, including 9 severe droughts. In the past 20 years, severe droughts occurred many times in the upper and middle reaches of the Yellow River Basin, resulted in a significant yield reduction and very difficult to get drinking water for local people. The drought in 1997 caused record days of Yellow River cutoff and a record cutoff river length. Since 2000, the Yellow River almost saw successive years of drought, severe drought occurred in 2008 and 2010, resulted in agricultural huge losses. Yellow River Basin is a resource-based water shortage area, contradiction in water supply and demand in arid years becomes more prominent, irrigation water is limited, in this sense, the quantitative study of the relationship between meteorological drought and irrigated water demand is of great significance for the rational organization of irrigation water 
Table 1. Main irrigation districts and there characteristics index in the Yellow River basin.

\begin{tabular}{|c|c|c|c|c|c|c|c|}
\hline Name of irrigation district & Location & $\begin{array}{r}\text { Effective } \\
\text { irrigation } \\
\text { area } \\
\left(\mathrm{h} \mathrm{m}^{2}\right)\end{array}$ & $\begin{array}{l}\text { Precipitation } \\
\text { station } \\
\text { number } \\
\text { (set) }\end{array}$ & $\begin{array}{c}\text { Evaporator } \\
\text { station } \\
\text { number } \\
\text { (set) }\end{array}$ & $\begin{array}{c}\text { Annual } \\
\text { mean } \\
\text { precipitation } \\
(\mathrm{mm})\end{array}$ & $\begin{array}{r}\text { Annual } \\
\text { mean } \\
\text { evaporation } \\
\text { capacity } \\
(\mathrm{mm})\end{array}$ & $\begin{array}{r}\text { Groundwater } \\
\text { buried depth } \\
\text { (m) }\end{array}$ \\
\hline Qingtongxia irrigation district & Xiaheyan to Shizhuishan reaches & 44.1 & 12 & 8 & 196.0 & 900.7 & $0.5-3.0$ \\
\hline Hetao irrigation district & Shuizuishan to Hekouzhen reaches & 55.9 & 15 & 10 & 200.2 & 1257.5 & $0.6-2.7$ \\
\hline Fen river irrigation district & $\begin{array}{l}\text { Taiyuan basin of middle Shanxi } \\
\text { at Fen River Basin }\end{array}$ & 44.2 & 18 & 9 & 491.5 & 899.4 & $1.0-30.0$ \\
\hline Wei river irrigation district & $\begin{array}{l}\text { Guanzhong Plain of Shannxi at Wei } \\
\text { River Basin }\end{array}$ & 83.5 & 19 & 12 & 543.8 & 1144.5 & $5.0-20.0$ \\
\hline $\begin{array}{l}\text { Irrigation district in lower } \\
\text { reaches of the Yellow River }\end{array}$ & $\begin{array}{l}\text { Henan, Shandong below } \\
\text { Huanyuankou reaches }\end{array}$ & 220.0 & 24 & 15 & 672.7 & 886.9 & $0.5-5.0$ \\
\hline
\end{tabular}

sources. Extensive research of drought assessment both at home and abroad has been carried out, fruitful results have been achieved, however, quantitative research of the relationship between drought and irrigation requirement is less. Take the main irrigation districts of Yellow River basin as the study areas; this paper presents the quantitative study of the relationship between irrigation requirement and meteorological drought, aims to providing a scientific basis for the Yellow River drought mitigation.

\section{Overview of irrigation districts}

Climatic conditions and Water resources in the Yellow River basin determine the development of agriculture relies heavily on irrigation, large and medium irrigation districts play a pivotal role in agricultural production. Agricultural bases in the Yellow River basin are concentrated in plains and channel basins. For example, Ningxia-Inner Mongolia Hetao Plain in the upper reaches of Yellow River is the successful model in building "oasis agriculture" in arid area, Fen-Wei basin in the middle reaches is one of key agricultural production bases, the irrigation district in the lower Yellow River, located at Huang-Huai-Hai plain, is the major grain producing area in China. This study takes the Qingtongxia irrigation district and Hetao irrigation district in the upper reaches, Fen river irrigation district and Wei river irrigation district in the middle reaches, and Yellow River irrigation district in the lower reaches as study areas. The main irrigation districts and their characteristics index are given in Table 1.

The data referred to in this study include: hydrology, meteorology, groundwater and crop parameters. Hydrological, meteorological data refer to such data cluster as precipitation, evaporation, temperature, pressure, sunshine duration, wind speed and relative humidity from 1956 to 2010 of main irrigation districts and neighbored 142 weather stations (including 88 precipitation stations and 54 evaporator stations) as released by National Climate Information Center of China Weather Bureau, the groundwater level data refers to groundwater monitoring and correlation study fruits of Yellow River (Chen and Liu, 2013; Sun et al., 2014; Wu, 2009; Zhao et al.,
2009), crop parameter refers to the survey and statistic of comprehensive planning of water resources of Yellow River and CROP database of FAO (MOA, 2009).

\section{Drought assessment of irrigation district}

\subsection{Indices and methods for drought assessment of irrigation district}

Meteorological drought means the abnormal water shortages as caused by the imbalance of precipitation and evaporation, which can be characterized by precipitation, evaporation ratio or statistics. The agricultural drought means that output reduction or output failure may occur when normal growth of crop is affected due to crop water imbalance, water deficit as caused by environmental factors or human activities. If not considering the intervention of human activities, meteorological drought is the only driving factor of agricultural drought, so selection of rational meteorological drought index is the key for quantitative analysis of the relationship between meteorological drought and irrigation requirement.

Common meteorology drought index can be divided into single factor indicator, dual-factor indicator and multivariate indicators (Wang et al., 2011, 2012; Zhang et al., 2007). Single factor indicator includes precipitation or accumulated precipitation anomaly percentage, precipitation or accumulated precipitation standardized statistic standardized precipitation index (SPI), etc., the calculation of which is simple, only regarding statistic of precipitation as the characterization indicator of meteorology drought, incapable of reflecting the whole characteristic of meteorology drought; dual-factor indicator, such as $K$ index of aridity, reconnaissance drought index (RDI), and so on, such index uses the precipitation and evaporation ratio or the statistic thereof to character the meteorology drought, thus reflecting drought from the view of water balance. Multivariate index involves a typical Palmer drought index (PDSI) established based on soil water equilibrium principle, so the calculation method is more complicated. 
In combination with the meteorological drought characteristics of Yellow River irrigation district, we can select RDI as the drought evaluation index of typical irrigation district. Compared with other indicators, RDI has the following advantages (Tsakiris and Vangelis, 2005; Eleanor and Simon, 2010; Ashok and Vijay, 2011): (1) capable of applying to drought assessment at river basin, region or other different levels; (2) suitable for drought assessment at any time or scale; (3) using the cumulative deficit between rainfall and evaporation to characterize the drought, having decisive physical significance; (4) compared with single factor index, RDI takes into account precipitation, evaporation factor, while the evaporation is affected by many climatic factors such as temperature, humidity, sunshine, so more sensitive to environmental changes, suitable for regional/basin drought evaluation under conditions of climate; (5) capable of establishing effective links with the soil water deficit; (6) since the data is relatively easy to be obtained, the calculation method is not complicated.

RDI calculation method: As for an evaluated area, assuming that there are $n$ evaluation periods, the ratio $x_{i}$ of precipitation $P_{i}$ to potential evaporation $\mathrm{PET}_{i}$ can be calculated following Eq. (1):

$x_{i}=\frac{P_{i}}{\operatorname{PET}_{i}}, \quad i=1,2, l \ldots, n$.

Assuming $x_{i}$ is stochastic variable $x$ and subjected to $\Gamma$ distribution, the probability density distribution function $f(x)$, based on sample data, can be following Eq. (2):

$f(x)=\frac{1}{\beta^{\gamma} \Gamma(x)} x^{\gamma-1} e^{-x / \beta}, \quad x>0$

where $\beta>0, \gamma>0$ are respectively for scale parameter and shape parameter of Probability Density Function, which can be came at by maximum likelihood estimate method. As for the ration $x_{i}$ of precipitation to potential evaporation at some period, the probability stochastic variable $x$ is less than $x_{i}$ can be acquired based on Eq. (3); if $x_{i}=0$, the probability which stochastic variable $x$ is less than $x_{i}$ can be estimated based on Eq. (4).

$F\left(x<x_{i}\right)=\int_{0}^{\infty} f(x) \mathrm{d} x$

$F\left(x_{i}=0\right)=k / n$

where $k$ is for sample number when $x_{i}=0 ; n$ is for total sample number, i.e. the number at evaluated period.

If normally standardized treatment of Probability Distribution Function $n\left(x<x_{i}\right)$, we can get Eq. (5), the functional morphology parameter $z$ value is the purposed RDI value. The evaluation criteria of RDI see Table 2.

$F\left(x<x_{i}\right)=\frac{1}{\sqrt{2 \pi}} \int_{0}^{\infty} e^{-z^{2} / 2} \mathrm{~d} x$
Table 2. Grading classification of meteorology drought based on RDI.

\begin{tabular}{lll}
\hline Status & RDI & Grade \\
\hline 0 & $-0.5<\mathrm{RDI}$ & No drought \\
1 & $-1.0<\mathrm{RDI} \leq-0.5$ & Light drought \\
2 & $-1.5<\mathrm{RDI} \leq-1.0$ & Medium drought \\
3 & $-2.0<\mathrm{RDI} \leq-1.5$ & Heavy drought \\
4 & RDI $\leq-2.0$ & Special drought \\
\hline
\end{tabular}

\subsection{Drought evaluation of irrigation district based on RDI}

RDI is used to have an evaluation of drought in main irrigation districts of upper, middle and lower reaches of Yellow River in 1956 to 2010, the results are given in Fig. 1. The irrigation districts experienced 86 droughts, including 11 severe droughts, which is in reasonable agreement with the typical drought conditions as recorded historically for Yellow River, for example, the oversized drought occurring in 1965, 1966, 2005, 2009 and 2010. From the view of drought conditions at various irrigation districts, Qingtongxia irrigation district experienced 18 droughts, most severe in 1980s; Hetao irrigation district experienced 21 droughts, most severe in 1980s; Wei River irrigation district experienced 20 droughts, most severe since 2000; Fen river irrigation district experienced 17 droughts, most severe in 1990s; Yellow River irrigation district in the lower reaches experienced 10 droughts, relatively severe in 1950 to 1960 , and 1980s. From the view of drought changing trend, the RDI value of irrigation districts in the upper and middle reaches trends toward decrease, which shows that drought trends toward exacerbated; the RDI value of irrigation districts in the lower reaches trends toward increase, the drought may be somewhat alleviated.

\section{Irrigation requirement of irrigation districts}

\subsection{Water demand for crop irrigation}

Crop irrigation requirement means the irrigation quantity required for high yield during overall growing season under feasible soil moisture and fertility level, which can be inquired into through field water layer (or soil moisture) dynamic equilibrium in a simulation way. The water source available for crop includes effective precipitation, soil water and groundwater-recharged water quantity, the crop irrigation is intended to supplementing plant transpiration soil evaporation of water. Since dry crop is mainly planted along the Yellow River, the net irrigation requirement during growing season is subjected to water balance theory, and the water balance formulae is given following Eq. (6):

$Q_{i}=\mathrm{ET}_{\mathrm{c}_{i}}-\mathrm{Pe}-\mathrm{Ge}_{i}+\Delta W$

where $Q_{i}$ is for net irrigation requirement(mm) of $i$ th crop; $\mathrm{ET}_{\mathrm{c}_{i}}$ is for evaporative capacity of $i$ th crop transpira- 
tion (mm), $\mathrm{ET}_{\mathrm{c}_{i}}=K_{\mathrm{c}_{i}} \times \mathrm{ET}_{0}, \mathrm{ET}_{0}$ is for evaporative capacity of reference crop transpiration, which can be calculated by Penman-Monteith formulae as recommended by FAO; $K_{\mathrm{c}_{i}}$ is for crop coefficient, adopting different value depending on different growing phases; Pe is for monthly effective precipitation $(\mathrm{mm})$ during growing season, which can be calculated based on monthly rainfall during crop growing season and available factor at irrigation district; $\mathrm{Ge}_{i}$ is for the groundwater utilization quantity $(\mathrm{mm})$ during $i$ th crop growing season, the groundwater utilization is the function for the Setting Depth and evapotranspiration conditions under some soil texture and crop conditions: $\mathrm{Ge}=f(H) \times \mathrm{ET}_{\mathrm{c}_{i}}$, of which $f(H)$ is for the coefficient of groundwater utilization, relating to the groundwater Setting Depth, for example, when groundwater level ranges from 1 to $3 \mathrm{~m}$, Ge may take 30 to $10 \%$ of $\mathrm{ET}_{\mathrm{c}_{i}}$, when groundwater level is more than $3 \mathrm{~m}$, the crop groundwater utilization quantity can be ignored; $\Delta W$ is for the variation of soil moisture storage capacity of planned wet-layer soil during growing season, in case of study of crop water demand at long period, the variation of moisture storage capacity can be ignored.

\subsection{Irrigation requirement in irrigation districts}

The water demand in irrigation district relates to planted crops and sown area in irrigation district, the calculation of it needs to take into account the planting structure, sown area of leading crops, net ration of irrigation requirement for crop, irrigation water use factor and so on. In order to analyze annual change of water demand order in irrigation district and its response to drought index fluctuation, we can analyze irrigation requirement in irrigation district under identical crop planting structure, soil condition and irrigation water management model at 2010 level. The planting structure of crops in irrigation districts of upper, middle and lower reaches of Yellow River is given in Table 3.

From the view of decadal variations of irrigation water demand, the change of water demand of irrigation districts of Yellow River in 1956 to 2010 is opposite in direction to the drought index fluctuation, i.e. the irrigation requirement is large when drought index is small, but small when large; the maximum water demand in Qingtongxia irrigation district appeared in 1980s, minimum water demand in 1956 to 1969, the maximum water demand in Hetao and Fen river irrigation districts appeared after 2000, the maximum water demand in Wei river irrigation district appeared in 1990s, while that in Yellow River irrigation district in the lower reaches appeared in 1956 to 1969. The water demand of main irrigation districts of Yellow River in different periods is given in Table 4.
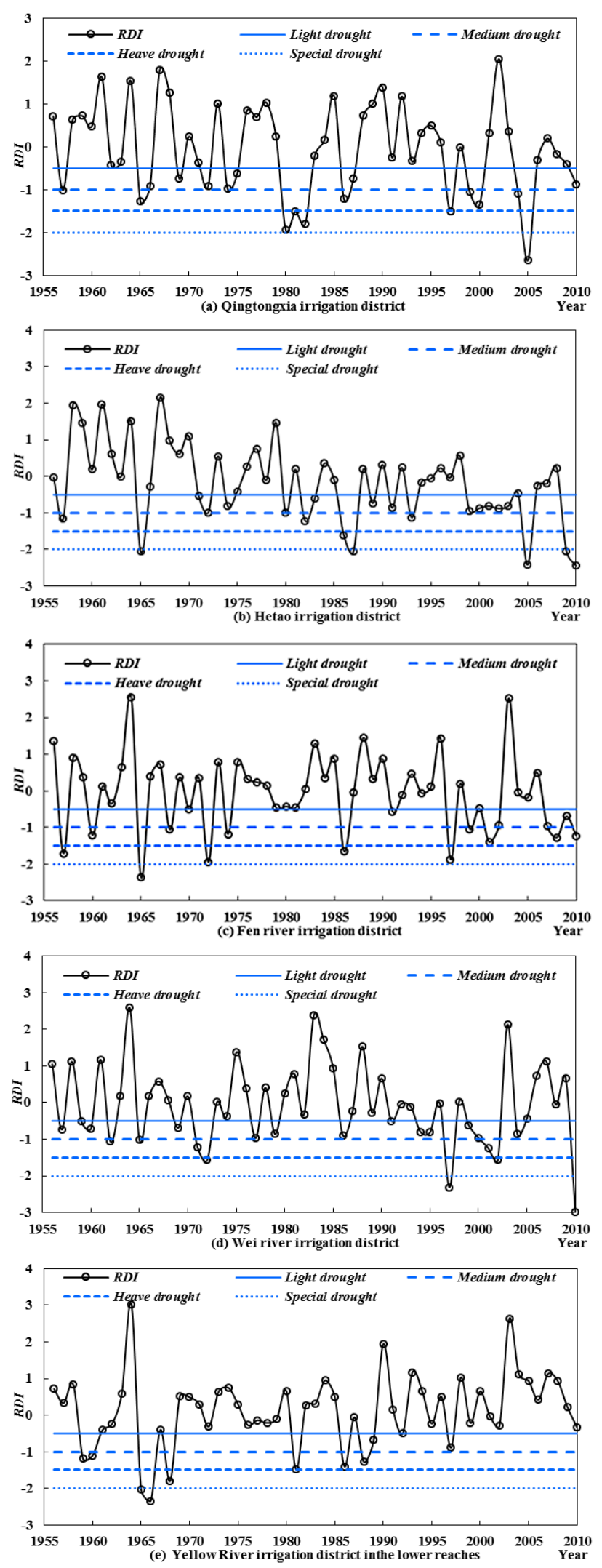

Figure 1. Evaluation results of drought of main irrigation districts of Yellow River basin. 
Table 3. Agricultural planting structure of main irrigation districts of Yellow River in 2010.

\begin{tabular}{|c|c|c|c|c|c|c|c|c|c|c|c|}
\hline \multirow[b]{2}{*}{ Name of irrigation district } & \multicolumn{4}{|c|}{ Grain crop (\%) } & \multicolumn{5}{|c|}{ Economic crop (\%) } & \multicolumn{2}{|c|}{$\begin{array}{l}\text { Forest and grassland } \\
\text { farming }(\%)\end{array}$} \\
\hline & Rice & wheat & corn & $\begin{array}{l}\text { Coarse } \\
\text { cereals }\end{array}$ & Cotton & $\begin{array}{r}\text { Oil } \\
\text { plants }\end{array}$ & $\begin{array}{c}\text { Melon } \\
\text { and } \\
\text { fruit }\end{array}$ & Vegetables & Others & $\begin{array}{r}\text { Forest } \\
\text { fruit }\end{array}$ & Pasture \\
\hline Qingtongxia irrigation district & 22.1 & 13.4 & 41.5 & 0.0 & 0.0 & 1.7 & 0.0 & 11.2 & 0.0 & 10.1 & 0.0 \\
\hline Hetao irrigation district & 0.0 & 17.9 & 24.0 & 3.6 & 0.0 & 27.9 & 2.5 & 5.3 & 8.5 & 4.8 & 5.7 \\
\hline Fen river irrigation district & 0.0 & 33.7 & 40.5 & 6.1 & 0.0 & 3.4 & 0.5 & 1.8 & 13.9 & 0.0 & 0.0 \\
\hline Wei river irrigation district & 0.0 & 23.7 & 16.5 & 1.7 & 0.0 & 39.1 & 6.7 & 6.1 & 0.0 & 0.0 & 6.1 \\
\hline Yellow River irrigation district & 6.8 & 29.5 & 28.3 & 5.2 & 0.3 & 4.8 & 5.4 & 7.9 & 2.2 & 9.6 & 0.0 \\
\hline
\end{tabular}

Table 4. Irrigation requirement of main irrigation districts of Yellow River in different periods (unit: 0.1 billion $\mathrm{m}^{3}$.

\begin{tabular}{lccccr}
\hline Periods/year & $\begin{array}{c}\text { Qingtongxia } \\
\text { irrigation } \\
\text { district }\end{array}$ & $\begin{array}{c}\text { Hetao } \\
\text { irrigation } \\
\text { district }\end{array}$ & $\begin{array}{c}\text { Fen River } \\
\text { irrigation } \\
\text { district }\end{array}$ & $\begin{array}{c}\text { Wei River } \\
\text { irrigation } \\
\text { district }\end{array}$ & $\begin{array}{r}\text { Yellow } \\
\text { River } \\
\text { irrigation } \\
\text { district } \\
\text { in lower } \\
\text { reaches }\end{array}$ \\
\hline $1956-1969$ & 49.59 & 47.75 & 22.56 & 33.37 & 102.52 \\
$1970-1979$ & 53.03 & 51.00 & 25.18 & 38.36 & 89.03 \\
$1980-1989$ & 54.57 & 53.94 & 24.45 & 35.45 & 100.47 \\
$1990-1999$ & 52.77 & 52.81 & 25.68 & 43.05 & 88.85 \\
$2000-2010$ & 54.39 & 54.77 & 30.27 & 41.46 & 91.04 \\
\hline
\end{tabular}

\section{Relationship between irrigation requirement and drought in irrigation districts}

\subsection{Link mechanism between drought and irrigation requirement}

From the view of overall growth of crop, the moisture source includes precipitation, groundwater utilization and overhead damping. At initial period of drought, the reduced available precipitation results in reduced soil moisture, the crop begins to adjust the guidance degree of its pore, thus reducing somewhat transpiration evaporative capacity and maintaining the body water equilibrium; when the drought goes forward, the soil moisture content drops continuously, when exceeding over its conditions and abilities, the moisture deficit occurs, simultaneously, drought development causes such climatic factors as air temperature, humidity, illumination, wind speed and so on developing toward the direction in favor of evaporation, in this way the transpiration evaporative capacity of crop increases, irrigation requirement is also large.

\subsection{Analysis of correlation between drought and irrigation requirement}

In order to make clear the relation between drought in irrigation district and irrigation requirement, we can use grey correlation analysis method to judge the relevance size according to the resemblance between discrete data of gray system, and the correlation degree is the measurement to reflect the size of the nearness level. We can use grey correlation analysis method to calculate the grey correlation degree between them, regarding drought index RDI of irrigation district as the reference sequence, regarding irrigation requirement in irrigation district as the comparison sequence. Prior to the correlation analysis, we may have a dimensionless treatment of reference sequence and comparison sequence, use standardized treatment.

$S_{i}(t)=\frac{x_{i}(t)-\overline{x_{i}}}{\sigma}$

where $i=0,1$ is for reference sequence and comparison sequence, $t=1,2, \ldots, N$.

The absolute error between comparison sequence and reference sequence at $t$ time is:

$\Delta(t)=S_{1}(t)-S_{0}(t)$.

The maximum difference is:

$\Delta_{\max }=\max \left|S_{1}(t)-S_{0}(t)\right|$.

The minimum difference is:

$\Delta_{\min }=\min \left|S_{1}(t)-S_{0}(t)\right|$.

The correlation coefficient of two sequences at $t$ time is:

$\xi(t)=\frac{\Delta_{\min }+0.5 \Delta_{\max }}{\Delta(t)+0.5 \Delta_{\max }}$. 
Table 5. Correlation relationship between irrigation requirement and RDI drought index of main irrigation districts of Yellow River.

\begin{tabular}{lccccc}
\hline $\begin{array}{l}\text { Name of irrigation } \\
\text { district }\end{array}$ & $\begin{array}{c}\text { Qingtongxia } \\
\text { irrigation } \\
\text { district }\end{array}$ & $\begin{array}{c}\text { Hetao } \\
\text { irrigation } \\
\text { district }\end{array}$ & $\begin{array}{c}\text { Wei River } \\
\text { irrigation } \\
\text { district }\end{array}$ & $\begin{array}{c}\text { Fen River } \\
\text { irrigation } \\
\text { district }\end{array}$ & $\begin{array}{c}\text { Yellow River } \\
\text { irrigation } \\
\text { district } \\
\text { in lower } \\
\text { reaches }\end{array}$ \\
\hline $\begin{array}{l}\text { Grey correlation degree } r \\
\text { Related coefficient } R\end{array}$ & 0.596 & 0.614 & 0.694 & 0.671 & 0.719 \\
\hline
\end{tabular}

Correlation degree of two sequences is:

$r=\frac{1}{N} \sum_{t=1}^{N} \xi(t)$.

In order to prove the relationship between irrigation requirement and drought at irrigation district, we can use related coefficient for demonstration; the correlation analysis between irrigation requirement and drought index of main irrigation districts of Yellow River from 1956 to 2010 and analytic results of related coefficient are given in Table 5 .

The analytic result concerning grey correlation degree between irrigation requirement and RDI drought index of key irrigation districts of Yellow River shows that their grey degrees of association are both more than 0.5 , which reveals that they two have high relevance; from the view of value change of grey correlation degree, the correlation degree from the upper to the lower reaches increases gradually, while that of Qingtongxia irrigation district is the least at 0.596, that of Yellow River irrigation district in the lower reaches is the maximum at 0.719 , which shows that the relevance between irrigation requirement of irrigation district of upper reaches and RDI is weaker than the lower reaches. In order to judge the correlation nearness level between irrigation requirement and drought in irrigation districts, we can use correlation coefficient for demonstration, the correlation coefficient spans $[-1,1]$, if $|R|$ value is more approaching to 1 , which shows the linearly dependent level between irrigated requirement and $\mathrm{RDI}$ is higher, if $|R|$ value is more approaching to 0 , which shows that their linearly dependent level is lower, when $|R|$ value is greater than 0.5 , it can be believed that they have significant linearly dependent relationship. Through the analysis of correlation coefficient between irrigation requirement and RDI in main irrigation districts, the correlation coefficient of Qingtongxia is 0.368 , less than 0.5 , so is low correlation, the correlation coefficient of other irrigation districts is greater than 0.5 , so is significant correlation, which shows that linearly correlativity exists between irrigation requirement and RDI, and the spatial variation law is basically consistent with grey correlation degree, correlation coefficient from upper to lower reaches trends toward increase.

From the view of main factors affecting irrigation requirement and drought, the annual mean precipitation of Qing- tongxia irrigation district is only $196 \mathrm{~mm}$, annual mean evaporative capacity is $900.7 \mathrm{~mm}$, groundwater level maintains at 0.5 to $3 \mathrm{~m}$, the total evapotranspiration of crop is large, efficient utilization quantity of rainfall is small, the moisture supplementation during growing season gives priority to irrigation and groundwater utilization, the irrigation requirement is less affected by meteorological factor fluctuation, and the correlation degree with RDI in the irrigation district is the least; annual mean precipitation of Hetao irrigation district is $200.2 \mathrm{~mm}$, annual mean evaporative capacity is $1257.5 \mathrm{~mm}$, permanent ground-water level ranges from 0.63 to $2.68 \mathrm{~m}$, the available effective precipitation of crop is less while groundwater utilization quantity is large, the irrigation requirement is less affected by meteorological factors, and the correlation degree with RDI in the irrigation district is relatively small; the mean annual precipitation at Fen River and Wei irrigation districts in the middle reaches is $500 \mathrm{~mm}$ or above, the groundwater level of most areas is more than $5 \mathrm{~m}$, the available groundwater utilization is limited, and its specific gravity increases by crop available rainfall, the impact of irrigation requirement by Irrigation District factors is gradually increased, the correlation degree and correlation coefficient between irrigation requirement and RDI are both larger; the precipitation of Yellow River irrigation district in the lower reaches is 600 to $800 \mathrm{~mm}$, the effective rainfall serves as the main water source for growing season, therefore, irrigation requirement is susceptible to the influence by meteorological factors, the correlation degree and correlation coefficient between irrigation requirement and RDI is the maximal. Upon the comprehensive analysis of relationship between irrigation requirement and RDI, it shows that with the increase of annual mean precipitation (the increase of crop available effective precipitation), the incidence relation between irrigation requirement and RDI is enhanced.

\subsection{Quantitative relation between irrigation requirement and drought index}

Regression analysis is a sort of mathematical statistics method to treat the correlativity between variables (Chen et al., 1995). Regarding RDI drought index as the argument, and regarding irrigation requirement of irrigation district as the dependent variable, we can use least square method to establish regression equation for irrigation requirement and 
Table 6. Drought index regression between irrigation requirement and RDI of main irrigation districts of Yellow River.

\begin{tabular}{lcc}
\hline Irrigation district & $\begin{array}{c}\text { Irrigation requirement-drought } \\
\text { index regression equation }\end{array}$ & $\begin{array}{c}t \text { test } \\
\text { value }\end{array}$ \\
\hline Qingtongxia irrigation district & $Q=-1.3593 \mathrm{RDI}+53.279$ & 26.576 \\
Hetao irrigation district & $Q=-2.8136 \mathrm{RDI}+51.774$ & 48.488 \\
Fen River irrigation district & $Q=-3.8019 \mathrm{RDI}+25.648$ & 56.664 \\
Wei River irrigation district & $Q=-4.9569 \mathrm{RDI}+38.413$ & 61.463 \\
Yellow River irrigation district & $Q=-12.431 \mathrm{RDI}+92.292$ & 98.731 \\
in lower reaches & & \\
\hline
\end{tabular}

RDI of main irrigation districts of Yellow River to study the correlativity between irrigation requirement and RDI and find out the inherent law (Li, 2011; Tong, 2007; Chen, 2010; Wu and Zhao, 2010; Zhang et al., 2008). To prove whether or not there is significance in the equation of linear regression for irrigation requirement and RDI, we have a $t$ test of reliability. Under the $t$ distribution in which the degree of freedom is 53 ( $n-2, n$ study order years' number 55$)$ and confidence level $\alpha=0.05$, the critical value of $t$ distribution, and the proven result is given as follows: the $t$ test value of regression equation is far greater than proven critical value 2.0091, which shows that there exists significant linear relationship between irrigation requirement and RDI. The equation for irrigation requirement and $\mathrm{RDI}$ of main irrigation districts to use regression analysis is given in Table 6 .

From the view of regression relation between irrigation requirement and drought index of Yellow River, we discovered that with the decrease of RDI index (drought level increases), the irrigation requirement increases. The irrigation requirements of all irrigation districts are different in response to RDI change, for example, the response of irrigation requirement of irrigation district in the upper reaches to RDI change is week relatively, while that in the middle and lower reaches is strong relatively. When RDI index of Qingtongxia irrigation district in the upper reaches decreases by 0.1 , the irrigation requirement increases 0.0136 billion $\mathrm{m}^{3}$; when drought increases by one grade (RDI index decreases by 0.5 ), irrigation requirement on average increases 0.068 billion $\mathrm{m}^{3}$; when RDI index of Hetao irrigation district decreases by 0.1 , the irrigation requirement increases 0.0281 billion $\mathrm{m}^{3}$; when drought increases by one grade, irrigation requirement on average increases 0.141 billion $\mathrm{m}^{3}$; when RDI index of Fen River irrigation district in the middle reaches decreases by 0.1 , the irrigation requirement increases 0.0380 billion $^{3}$; when drought increases by one grade, irrigation requirement on average increases 0.190 billion $\mathrm{m}^{3}$; when RDI index of Wei River irrigation district in the middle reaches decreases by 0.1 , the irrigation requirement increases 0.0496 billion $\mathrm{m}^{3}$; when drought increases by one grade, irrigation requirement on average increases 0.248 billion $\mathrm{m}^{3}$; when RDI index of Yellow River irrigation districts in the lower reaches decreases by 0.1 , the irrigation requirement increases 0.1243 billion $\mathrm{m}^{3}$; when drought increases by one grade, irrigation requirement on average increases 0.622 billion $\mathrm{m}^{3}$.

\section{Conclusions}

1. Meteorology drought is the major driving factor of agricultural drought. Based on the analysis of existing drought evaluation method and characteristic, we use RDI drought index to evaluate the drought condition in main irrigation districts of Yellow River in 1956 to 2010 , the evaluation results are basically consistent with recorded drought of irrigation district of Yellow River, which shows that it is suitable for the drought evaluation of irrigation district of Yellow River. From the view of development trend of drought of irrigation district as evaluated by RDI, the drought degree of irrigation districts in the upper, middle reaches of Yellow River increases to some extent, the drought degree of irrigation districts in the lower reaches somewhat decreases.

2. In consideration of planting structure in the irrigation districts, sown area of leading crop, net irrigation requirement of crop and utilization coefficient of irrigation requirement and other factors, we use crop water balance equation to analyze and calculate the sequence irrigation requirement of main irrigation districts in 1956 to 2010, which shows that the irrigation requirement fluctuation is synchronized with and opposites in direction to the change of drought index (i.e. the irrigation requirement is large for the period when drought index is small).

3. The grey correlation degree and related data are applied to analyze the relationship between irrigation requirement of irrigated areas in Yellow River and drought index, which shows the significant relationship exists between them, increases with the increasing rainfall in irrigation district (the crop's efficient rainfall utilization also increases), the response of irrigation requirement to meteorological factors is enhanced, the correlation between irrigation requirement of middle and lower reaches and drought index is apparently higher than that of upper reaches. The regression analysis of irrigation requirement and drought index shows that with the reduction of RDI (drought grade increases), irrigation requirement increases, the response of irrigation requirement in different irrigation districts to drought index change is different, when drought is advanced with one grade (RDI index reduced by 0.5 ), irrigation requirement of Qingtongxia and Hetao irrigation districts in the upper reaches on average increases 0.105 billion $\mathrm{m}^{3}$, that of Fen river and Wei river Districts in the middle reaches increases 0.219 billion $\mathrm{m}^{3}$, that of Yellow 
River irrigation district in the lower reaches increases 0.622 billion $\mathrm{m}^{3}$.

\section{Data availability}

All the data sets we used in the article were publicly accessible, the meteorological data was released by National Climate Information Center of China Weather Bureau, accessed at http://www.data.cma.cn, and other data sets like characteristic of irrigation districts of Yellow River basin can be obtained on Water Resources Bulletin for Yellow River accessed at http://www.yellowriver.gov.cn/other/hhgb/ published by Yellow River Conservancy Commission.

Acknowledgements. This work was jointly supported by the project of the National Key Technologies R \& D Program (Grant No. 2013BAC10B02) and the National International Scientific and Technological Cooperation of China (Grant No. 2013DFG70990).

\section{References}

Ashok, K. M. and Vijay, P. S.: Drought modeling - A review, J. Hydrol., 403, 157-175, doi:10.1016/j.jhydrol.2011.03.049, 2011.

Chen, J. W.: Impact of climate change on irrigation requirement of typical crop of Heihe river basin, J. Irrig. Drain., 3, 69-73, 2010.

Chen, Y. C. and Liu, H. L.: Research on the relationship between groundwater of Qingtongxia irrigation district and soil salinization, Value Eng., 2, 311-313, 2013.

Chen, Y. M., Guo, G. S., Wang, G. X., Kang, S. Z., Luo, H. B., and Zhang, D. Z.: Water demand and irrigation of Chinese major crop, China Water Power Press, Beijing, 1995.

Eleanor, J. B. and Simon, J. B.: Regional drought over the UK and changes in the future, J. Hydrol., 394, 471-485, doi:10.1016/j.jhydrol.2010.10.003, 2010.
Li, Y. X.: Application of regression analysis in hydrological data processing, Natural Science, Chongqing University of Science and Technology, Chongqing, 5, 177-179, 2011.

New China Agricultural Statistics in 60 Years, China Agriculture Press, Beijing, Ministry of Agriculture of The People's Republic of China (MOA), 2009.

Sun, L. Y., Yang, S. Q., Li, F. J., Liu, D. P., and Chang, C. L.: Analysis of interaction of groundwater setting depth of Hetao irrigation district and concentration of Total Nitrogen, Water-Sav. Irrig., 7, 311-313, 2014.

Tong, L.: Study on the Response of agricultural water consumption in Shiyang river in northwest arid region to environmental changes, Xi'an, Doctoral Dissertation of Northwest Agriculture and Forestry University, Xi' an, 2007.

Tsakiris, G. and Vangelis, H.: Establishing a drought index incorporating evapotranspiration, Europe Water, 9/10, 3-11, 2005.

Wang, B., Wang, G. Z., Huang, J. B., Zhang, Z. Y., and Fu, Q.: Agricultural drought evaluation model and application, China Water Power Press, Beijing, 2011.

Wang, S. Y., Zheng, G. F., Yang, J., and Li, X.: Contrastive analysis of the application of several drought evaluation indexes in Ningxia, Chinese Deserts, 2, 517-524, 2012.

Wu, C. B.: Analysis of change law of groundwater setting depth of Fen river irrigation district, Groundwater, 2, 35-37, 2009.

Wu, P. T. and Zhao, X. N.: Impact of climate change on Chinese agriculture water and grain production, Agricult. Eng., 2, 1-6, 2010.

Zhang, Q., Deng, Z. Y., Zhao, Y. D., and Qiao, J.: Impact of global climate change on the agriculture in China northwest, J. Ecol., 3, 1210-1218, 2008.

Zhang, T. F., Wang, J. S., and Guo, J. Y.: Change characteristic of autumn drought index in northwest, Arid Reg. Res., 1, 87-92, 2007.

Zhao, J., Cai, M. K., Wei, X. M., Ning, Y. F., and Shen, B.: Analysis and prediction of Baojixia groundwater dynamic law, Groundwater, 6, 5-7, 2009. 